\title{
Tourist Satisfaction towards Management of Homestay in Lumajang District
}

\author{
$1^{\text {st }}$ Dewa Ketut Sujatha \\ Administrasi Perhotelan \\ Sekolah Tinggi Pariwisata Nusa Dua \\ Bali \\ Bali, Indonesia
}

\author{
$2^{\text {nd }}$ Ni Desak Made Santi Diwyarthi \\ Administrasi Perhotelan \\ Sekolah Tinggi Pariwisata Nusa Dua \\ Bali \\ Bali, Indonesia \\ santidiwyarthi@yahoomail.com
}

\begin{abstract}
This study aims to identify data relating to Tourist Satisfaction towards Management of Home Stay inLumajang District.Guests who come to stay at the hotel hope to get the best quality of service. Hotel management strives to provide services to suit guests' expectations. Homestay management offers personal services for guests. Guests can interact by enjoying the culture and doing something together with the community. Sample method is purposive random sampling, with a total of 112 respondents. Several data collection techniques used are interviews, observation, documentation and questionnaires with Likert scale.
\end{abstract}

There are six aspects measured, including Physical Form, Reliability, Responsiveness, Assurance, Empathy and Loyalty that affect tourist satisfaction towards management of homestay in Lumajang District. In the aspect of physical form, the highest Subaspect is a calm atmosphere, amounting to 3.63 (very good), next Sub-aspect is neatly arranged area, at 3.60 (very good), Subaspects of cleanliness and neatness of the room, at 3, 35 (Very good). In the aspect of reliability, the highest Sub-aspect is speed in service, at 3.51 (very good). Sub aspects of accuracy in serving tourists, amounting to 3.33 (Very Good). Sub aspects of employees who are sympathetic in offering assistance, amounting to 2.91 (Good).

In the aspect of Responsiveness, the Sub-aspects of responsiveness in assisting tourists is 3.16 (Very good). Sub aspects of clearly information, amounting to 3.07 (Good), and Sub aspects of employee willingness to help tourists who stay with points of 3.06 (Good). In the aspect of assurance, the security aspects is the highest points, which amounted to 2.99 (Good). Sub aspects in providing services with points of 2.67 (Good). And aspects of politeness and friendliness in service at points of 2.52 (Good). In the aspect of empathy, the Sub aspects of the attention of the manager and the owner of the tourist lodge towards individuals at points of 3.33 (Good). Sub-aspects of maintaining good relations with guests at points of 3.23 (Good). Then the Sub aspects of responsibility for comfort with points of 2.94 (Good). In Loyalty aspects, tourists have a good level of loyalty with points of 3.09 . Tourists want to come back, visit and stay at the home stay. In the Sub-aspects willingness to promote home stay, tourists also show a good response, with points of 2.90 . Tourists will give recommendations to other people to stay at the home stay that have been visited in Lumajang district.

Keywords—satisfaction, tourists, homestay

\section{INTRODUCTION}

Lumajang Regency is flanked by three beautiful mountains, namely Bromo, Semeru and Lemongan. As a well-known tourism destination, it already requires the involvement of the community in planning and managing the existence of the destination so that it can be sustainable and beneficial for the environment and the people in Lumajang Regency. Deny Rohman, Head of Cultural and Tourism Department in Lumajang Regency said, there is almost 37 destination in Lumajang District, and a lot of homestay. With 32.768 tourists visited Semeru mountain in 2017, the government establish the target of 6.7 billion tourist in 2018. Deny Rohman, Head of Cultural and Tourism Department in Lumajang Department said, at Beritajatim.com, "We already have one tourism village in 21 sub-districts with its supporting village". The 21 Tourism Villages include the Dirototrunan Village in Lumajang Subdistrict, Kutorenon Village in Sukodono Subdistrict, Wonorejo Village in Kedungjajang District, Tegal Randu Village in Klakah District, Ranu Bedali Village in Ranuyoso District, Ranuwurung Village in Randuagung District. Jatiroto Village in Jatiroto Subdistrict, Tanggung Village in Padang District, Argosari Village in Senduro District, Pasrujambe Village in Pasrujambe District, Jokarto Village in Tempeh Subdistrict, Selok Awar-awar Village in Pasirian District, Sidomulyo Village in Pronojiwo District, Sumbermujur Village in Candipuro District, Bulurejo Village in Tempursari District, Wonokerto Village in Tekung Subdistrict, Sidorejo Village in Rowokangkung District, Wotgalih Village in Yosowilanggun District, Gucialit Village in Gucialit District, Purwosono Village in Sumbersuko District. Of course the development of the tourism village requires the involvement of members of the village community, village officials, existing facilities and infrastructure. Deep community participation is expected to produce tourist villages that are well developed.

As a famous tourist area, the development of existing facilities and infrastructure also attracts visitors to come and stay longer, such as homestay located in the tourist area of Bromo Tengger Semeru. But there is still unsatisfaction comment about homestay in Lumajang Regency, about standarization of homestay, non capable 
staff, the room is not prepare well, not available menu at homestay.

Nyoman Matra (56 years) a guide said that:

"I bring tourists every month to visit Lumajang to 50 people. The obstacle is that sometimes tourist huts here cannot accommodate guests in accordance with the desired expectations. Like the type of room that is not in accordance with lodging standards, less professional workforce, poor room cleanliness, less varied food menu.

This study attempts to analyze tourist satisfaction with tourist huts in Lumajang District in terms of the quality of service. conduct tourist satisfaction analysis regarding the existence of Pondok Wisata located in Lumajang Regency, in terms of Attractions, Accessibility aspects, Amenities aspects, and Service aspects, based on the extent to which these aspects can satisfy tourists in terms of Reliable, Assurance, Empathy , Tangible, and Responsiveness.

\section{MAIN CONTENT}

\section{A. Theories}

Hotel Industries is a service industry with a combination of products and services. Quality is one of the keys to success for business. This quality is given to consumers in order to meet consumer expectations by providing products and services at a price level (Thio, 2001). According to Parasuraman in Tjiptono (2005: 273), service quality can be seen from five dimensions including: physical evidence, reliability, responsiveness, assurance and empathy. The level of customer satisfaction with the services of a company can be seen from customer satisfaction with the five dimensions of services offered by the company. Customers who experience service failures that they receive, tend to provide negative information to others about the service (Mattila in Sutomo, 2012).

The results of previous studies by Suradnya (1999) on the factors that attract foreign tourists to visit Bali include 9 factors, while in this study the number of tourist attraction factors that were identified were 8 factors. An interesting finding is that the "shopping or shopping" attraction factor no longer appears as a stand-alone attraction, but becomes part of the 8 newly formed factors, namely price and cultural attractiveness. This change can be explained by observing the fact that, (1) there is a tendency where tourists become more critical or cautious in spending their money as a result of a decrease in general purchasing power, (2) shopping or shopping is no longer a priority for tourism as they do travel, (3) the high number of repeat visits, which reached $47 \%$ so that the tourists became more aware of the level of prices in the tourist destinations visited.

The results of the research by Kurniati Istiqomah and Sri Purwantini regarding the Analysis of the Influence of Service, Service Quality and Prices on Customer Satisfaction (http://journal.usm.ac.id/jurnal/dinamikamanelola/232/detail/, downloaded January 15, 2015) regarding, shows the following results: (a) Service affects customer satisfaction. (b) Quality of Service affects customer satisfaction. This shows that customer satisfaction, in this case tourist satisfaction, is influenced by the services obtained, the quality of services, and the prices set.

Kotler (2000: 40) defines satisfied customers are customers who feel they get value from producers or service providers. This value can come from a product, service, system or something that is emotional. If customers say that value is a quality product, then satisfaction occurs when customers get quality products. If the value for the customer is convenience, then satisfaction will come if the service obtained is really comfortable.

Satisfied travelers are customers who will share satisfaction with producers or service providers. Even satisfied customers will share their taste and experience with other customers. This will be a reference for the company concerned. Therefore, both customers and service providers, will benefit equally if satisfaction occurs. By looking at this relationship, it is clear that customer satisfaction must be one of the main goals of each company.

Basically the purpose of a business is to satisfy customers. Satisfaction itself by Kotler (1997) in Rangkuti (2003: 23) is defined as a feeling of pleasure or disappointment of someone as a result of a comparison between achievement or perceived and expected products (a feeling of pleasure or disappointment resulting from comparing a product's received performance (or come out) in relations to the person expectation).

Satisfaction is a function of the impression of performance and hope. If performance is below expectations, customers are not satisfied. Conversely, if performance meets expectations, it means that customers are satisfied and if performance exceeds expectations, customers are very satisfied or happy. The expectations of buyers or customers are influenced by previous purchasing experience, advice from friends, colleagues, and the promises and information of marketers and competitors. If marketers increase expectations too high, buyers may be disappointed. Conversely, if the company sets expectations too low, buyers will not be interested. (Rangkuti, 2003: 23).

\section{B. Research Methods}

Sample method is purposive random sampling, with a total of 112 respondents. Several data collection techniques used are interviews, observation, documentation and questionnaires with Likert scale. Likert Scale used with four scale, is a scale that show consumer responses to the characteristics of a product (very good for point 3,01-4,00, good for point 2,01 - 3,00, enough for point $1,01-2,00$, and less for point $0-1,00)$, by Durianto et all (2001: 40)

\section{ANALYSIS}

\section{A. Respondents}

Lumajang Regency has a very promising hydrographic potential to be developed and processed related to the interests of the drinking water industry, irrigation and tourism. This is because Lumajang Regency has 31 rivers that flow throughout Lumajang Regency, there are also 369 
dams or water dams, 254 water pumps, six waterfalls, such as Coban Sewu, and lakes, such as Ranu Klakah, Ranu Pakis, Ranu Pane, Ranu Kumolo. This hydrographic potential provides enormous opportunities for development, drinking water, and various community interests, including the development of tourism, irrigation, industry and tourism. The existing lakes are characteristic of Mount Lamongan in Lumajang Regency which can be relied on for the tourism industry.

In Lumajang Regency there is also Mount Semeru which is the highest mountain on the island of Java. This mountain is a reliable potential of Lumajang Regency. These potentials include the results of material released in the form of stones, gravel and sand. In addition, this mountain is also one of the tourism icons of Lumajang Regency.

The population of Lumajang Regency until June 2016 was $1,104,759$ people. Land use in Lumajang Regency is quite diverse, ranging from technical rice fields, simple paddy fields, settlements, plantations, community forests, State forests, to pond lands, with varying proportions.

Senduro Subdistrict is the focus of the research, this subdistrict was chosen as the research population taking area.

Senduro Subdistrict population is 47,747 souls of Senduro Subdistrict Profile in 2016. The data of small-scale industry in Senduro Subdistrict includes banana chips, banana sale, pecel spices, taro / taro chips, cassava chips.

In Senduro Subdistrict, there are 12 villages, namely : Argosari, 30 homestay, Bedayu, 20 homestay, Bedayutalang, 15 homestay, Burno, 13 homestay, Kandangan, 12 homestay, Kandangtepus, 15 homestay, Pandansari, 25 homestay, Purworejo, 22 homestay, Ranupani, 17 homestay, Sarikemuning, 22 homestay, Senduro, 35 homestay, and Wonocepokoayu, 12 homestay. Totally 238 homestay at Senduro subdistrict.

Disparda of Lumajang Regency explained that tourists who come to visit various tourist destinations in Lumajang Regency can number more than 5000 people per month, with an average of 150 to 200 tourists per day. While the number of tourists staying at Pondok Wisata in Lumajang Regency is still far from expectations. Data from the Culture and Tourism Department in Lumajang District shows that there are more than 1,500 tourists per day staying at homestay. But the amount is not evenly distributed. For example, tourists stay at homestay located in Ranu Klakah, on average per month are only 20 to 50 people, out of the total number of rooms of 10 with each capacity of two people. The research population is tourists who come to visit and stay at homestay in Lumajang District.

Respondents are tourists who visit and stay at homestay in Lumajang Regency. The sampling technique used was purposive sampling. Purposive sampling is the technique of determining a sample that is determined intentionally (purposive) by considering certain criteria (Kusmayadi 2000: 75).

The theories used in this research based on Parasuraman in Tjiptono, also Bukart \& Medlik. There are five aspects that affect the tourist satisfaction. These five aspects are aspects of physical evidence, aspects of reliability, responsiveness aspects, assurance aspects, and aspects of empathy. Coupled with aspects of consumer loyalty.

The rating scale refers to Durmanto's theory (2014) with the following criteria:

$0.97-1.72=$ less

$1.73-2.48=$ enough

$2.49-3.24=$ good

$3.25-4.00=$ very good

According to Parasuraman in Tjiptono (2005: 273), service quality can be seen from five dimensions including: physical evidence, reliability, responsiveness, assurance and empathy. The level of customer satisfaction with the services of a company can be seen from customer satisfaction with the five dimensions of services offered by the company. Customers who experience service failures that they receive, tend to provide negative information to others about the service (Mattila in Sutomo, 2012)

Characteristics of respondents in this study amounted to 112 people, classified by gender, age, type of work, last education, how to obtain information about homestay, frequency of stay, reasons for overnight stay, and village tours in Lumajang District.

Research respondents have the characteristics of the age of tourists staying at homestay in Lumajang Regency as tourists aged 17 years to 55 years. The largest number of tourists who stay is $35.71 \%$, which is 40 people. Next with the second largest number of tourists aged 46 to 55 years, which amounted to $28.57 \%$ or 32 people. While tourists who stay at the lowest age are tourists aged over 55 years, which is $7.1 \%$ or 8 people.

Research respondents are tourists who come and stay at homestay in Lumajang Regency, and have diverse job variances, namely tourists who have jobs as entrepreneurs as many as 19 people or $16.96 \%$, tourists who have jobs as civil servants as many as 45 people or $40.18 \%$, tourists who stay at homestay with jobs as private employees as many as 18 people or $16.07 \%$, tourists who have jobs as students or students as many as 10 people or $8.93 \%$, and with other jobs, include drivers, guide, accountant, researcher, housewife, as many as 20 people or $17.86 \%$.

Most tourists stay at Pondok Wisata in Lumajang Regency because the information obtained from family or friends is 65 people, or $58.04 \%$, then 17 people, or $15.18 \%$ stay at homestay in Lumajang Regency because the information obtained from Media Electronics, as many as 15 people or $13.39 \%$ stayed at homestay in Lumajang Regency because of information obtained from the Travel Agent. About 10 people or $8.90 \%$ visited homestay in Lumajang Regency because the information obtained from the mass media was in the form of newspapers or magazines. A total of 5 people or $4.46 \%$ visited homestay in Lumajang Regency because of information obtained from the Tourist Information Center. .

\section{B. Data Analysis}

Tourists assume, homestay in Lumajang Regency with a pleasant atmosphere, neatly arranged areas, as well as 
cleanliness and tidiness of rooms is the reason tourists come to visit and stay at tourist huts.

The owner and staf of homestay can further increase the willingness to convey information and help tourists overcome the problems. For example, explaining the food menu, conveying customs, existing tourist destinations, transportation that can be used to reach the location

The owner and staf of homestay guarantee the quality of services obtained by tourists who stay in homestay are in good category. But it should be better improved. Tourists stayed at homestay understand standard and quality of service at homestay. The tourist hope the management should improve better quality of service in the homestay.

The owner and manager of the tourist lodge must increase the responsibility for security and comfort as long as the tourists stay at the tourist lodge. Sometimes there are types of tourists who do not want to be disturbed by greetings or joint discussions related to the introduction of customs and culture. There are other types of tourists who do not want to be disturbed by the delivery of menu dishes for them. Tourists want to come back, visit and stay at the tourist lodge in question. Tourists will give recommendations to other people to stay at the tourist huts that have been visited in Lumajang district.

\section{CONCLUSION AND SUGGESTION}

\section{A. Conclusion}

\section{a. Aspects of Physical Form}

In the Physical Form aspect, the highest sub-aspect is a calm atmosphere, amounting to 3.63 (very good), the next subaspect of the area is neatly arranged, amounting to 3.60 (very good), then sub-aspects of cleanliness and tidiness of the room, amounting to 3.35 (Very good).

\section{b. Reliability aspects}

In the aspect of reliability, the highest sub-aspect is the speed in service and handling tourist demand, amounting to 3.51 (Very good). The following sub aspects are accuracy in serving travelers who stay, at 3.33 (Very Good). The following sub aspects are sympathetic employees offering assistance, which is 2.91 (Good).

\section{c. Responding Aspects}

In the aspect of responsiveness, the sub-aspects of alertness of the owner or manager of the tourist lodge in helping tourists become the highest sub-aspect, amounting to 3.16 (Very good). This means that tourists feel very helped in dealing with the situation and the problems faced. Next sub aspects of clarity in conveying information, amounting to 3.07 (Good), and sub aspects of employee willingness to help tourists staying with points of 3.06 (Good).

\section{d. Guarantee Aspect}

In the Assurance Aspect, the security sub-aspects obtained when staying at a tourist lodge with the highest points, which amounted to 2.99 (Good). Next, the sub aspects of skills in providing services with points of 2.67 (Good). And aspects of politeness and friendliness in service with points of 2.52 (Good)

\section{e. Empathy Aspects}

In the aspect of Empathy, the highest sub-aspect is the attention of the manager and the owner of the tourist lodge towards the individual with a point of 3.33 (Good). The following is a sub-aspect of maintaining good relations with guests with points of 3.23 (Good). Then the sub aspects of responsibility for comfort with points of 2.94 (Good).

\section{f. Loyalty aspect.}

In the Loyalty aspect, tourists have a good level of loyalty. This is shown by a point of 3.09. Tourists want to come back, visit and stay at the tourist lodge in question. In the sub-aspects helped promote tourism huts, tourists also showed a good response, with points of 2.90. Tourists will give recommendations to other people to stay at the tourist huts that have been visited in Lumajang district

\section{B. Suggestion}

Although tourists feel satisfaction with homestay in Lumajang Regency, very good in aspects, physical, reliability, responsiveness, assurance, empathy and loyalty, various related parties still have to maintain and develop existing aspects. The owners and staffs at homestay and the community in Lumajang Regency need to involve other regions as comparison such as Malang Regency, Banyuwangi Regency, and even, Bali Province.

Lumajang Regency has a very promising hydrographic potential to be developed and processed

For papers published in translation journals, please give the English citation first, followed by the original foreignlanguage citation [6].

\section{REFERENCES}

[1] Bukart, and Medlik, "Tourism: Past, Present and Future" Grid Inc. Heinemann 1981

[2] Chen, Cheng Nan, "The Relation Among Social Capital, Enterpreneurial Orientation Organizational Resources and Enterpreneurial Performance for New Ventures, Contemporary Management Research", National Cheng Kung University, 2007.

[3] Friedman. J, "Anthropology and Native in Global Struggle for Identity", 1993.

[4] Jennings, Gayle, "Water - Based Tourism, Sport, Leisure, and Recreation Experiences", UK: Burlington. Elseiver Inc., 2007

[5] Rangkuti, Freddy, "Measuring Customer Satisfaction" Jakarta: PT Gramedia Pustaka Utama, 2003.

[6] Sihite, Richard, "Tourism Industry”, Surabaya: SIC, 2000. 